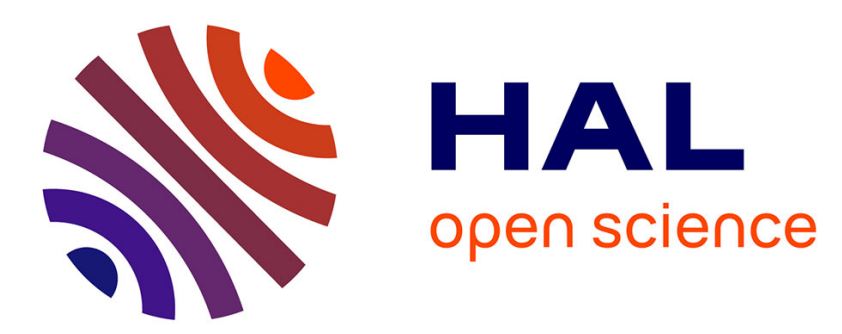

\title{
ICT in the Future Classrooms and Teaching: Preparing the Knowledge Workers of the 21st Century
}

\author{
Dimitrios Charalambidis
}

\section{To cite this version:}

Dimitrios Charalambidis. ICT in the Future Classrooms and Teaching: Preparing the Knowledge Workers of the 21st Century. 10th IFIP International Conference on Artificial Intelligence Applications and Innovations (AIAI), Sep 2014, Rhodes, Greece. pp.56-62, 10.1007/978-3-662-44722-2_7 . hal01391029

\section{HAL Id: hal-01391029 \\ https://hal.inria.fr/hal-01391029}

Submitted on 2 Nov 2016

HAL is a multi-disciplinary open access archive for the deposit and dissemination of scientific research documents, whether they are published or not. The documents may come from teaching and research institutions in France or abroad, or from public or private research centers.
L'archive ouverte pluridisciplinaire HAL, est destinée au dépôt et à la diffusion de documents scientifiques de niveau recherche, publiés ou non, émanant des établissements d'enseignement et de recherche français ou étrangers, des laboratoires publics ou privés. 


\title{
ICT in the Future Classrooms and Teaching: Preparing the Knowledge Workers of the 21st Century
}

\author{
Dr. Dimitrios Charalambidis \\ ${ }^{1}$ ICT Coordinator, "Saint Joseph" Hellenic-French School, \\ 2, Thessalonikis str., Pefki 151 21, Athens, Greece. \\ dimitrios.charalambidis@stjoseph.gr
}

\begin{abstract}
A knowledge worker is a person that adds value to an organization by processing existing information to create new information and knowledge that could be used to define and solve problems. The future classroom is the cradle (for students) and the action field (for teachers) of a knowledge worker. It incarnates the vision for learning and teaching with the use of Information, Communications and Technology tools (ICT) in order to provide to the students significant 21st century skills such as personal and social responsibility, critical thinking, digital competence, as well as collaboration and communication abilities. From the teacher's point of view it demands understanding and creative use of ICT tools, organizational and administrative competences, use of up-to-date teaching scenarios, intuitive assessment methods and most of all a "lead and teach by example" attitude. Building the future classroom is all about delivering competent and effective people to the society, people that will be the key stakeholders in a world that seeks innovation and creativity in order to keep going socially, scientifically, economically, etc. In this paper we will provide insights about the reasons why a future classroom teacher should afford 21st century skills to his students and continuous professional development to himself.
\end{abstract}

Keywords: ICT in education, knowledge workers, 21st century skills, 1 to 1 computing, future classroom scenarios, innovation in teaching and learning, professional development.

\section{Introduction}

Why is so important for a classroom teacher to afford 21st century skills to his students? To help us get a better feel for the changes coming to schooling and learning, let's take a few minutes and do a thought test, submitting four questions to ourselves.

First, imagine that we have a child whom we love and care about. Moreover, this child is about to start kindergarten this year. Question \#1: What will the world be like twenty years from now when our child finishes school? We can easily answer to that question if we try to remember what life was like twenty years ago and all the 
changes we have seen taking place until today. Question \#2: What skills will our child need to be successful in a world twenty years from now? Inexorably, this question generates most of the 21st century skills covered in this article, including hard and soft skills as well as knowledge, values and behaviors [1].

Secondly, let us change our point of view and imagine that we run a small business, an R\&D department or a university research laboratory. Furthermore, this business, $R \& D$ department or university lab is about to compete other innovative companies, R\&D departments or labs locally and abroad. Question \#3: What skills would we require from our staff in order to achieve innovative goals? This question also generates most of the times 21st century skills required from competitive business or academic environments.

Finally, let us look over our answers to the first three questions and consider how most students currently spend their time each and every day in school. Question \#4: What would teaching and learning be like if it were designed and implemented around our answers to the first three questions?

\section{Schooling: A Time for High-performance Cultures}

The final stage of the upper secondary Hellenic educational system called Lykeio is primarily focused on teaching and learning what will be tested in the big government exams (Panellinies). In this case the spirit of innovation is dead, considering that the main goal is to get good examination marks that will eventually lead to enrollment in a high educational institution. Ironically, students and their parents think that Lykeio is unable to fulfil this preparatory role in a satisfying way. As a result, they seek resource to private tutorial schools (frontistiria). Frontistiria, a purely Greek phenomenon, undergo intensive preparations for the country-wide exams (Panellinies) [2].

This innovation-hostile schooling culture deprives the students as well as the teaching staff of all the benefits that innovation can bring to an unchanging, and thus obsolescent and "human-eating", system. Why is this educational system obsolescent? Because, it delivers highly educated underskilled professionals. Therefore, it produces long-term unemployed or underpaid people. Besides, long-term unemployment leads to an erosion of skills and knowledge. Why is this educational system "humaneating”? Because, it produces greatly unhappy and desperate people.

An underdeveloped school is striving to succeed by standard methods and it is unable to make or sustain improvements. Additionally, a traditional school is effective by standard methods and seeks improvement within old-style pedagogical and managerial methods. On the other hand, an innovative school goes beyond standard methods and measures of success. It constantly evaluates how effectively it is preparing students with core academic and 21st century skills. Twenty-first century schools are first and foremost effective organizations by design. They are schools where innovation and continuous improvement are core values. They have strong leaders who create learning environments, which motivate and attract the best educators. They also use metrics and analytics, because they know what gets measured gets done efficiently. Overall, innovative schools build high-performance 
cultures. However, as mentioned before, what mostly characterizes these schools is a determination to prepare students for 21st century professions. The jobs of the future will be complex and will require innovative and creative thinking. Jobs that are not, will be done by computers.

\section{21st Century Skills: The World within and beyond the Classroom}

In order to thrive in a digital world, students will need digital age proficiencies. It is important for every educational system to fulfill its mission in society, namely the preparation of students for the world beyond the classroom. Therefore, schools must comprehend and embrace 21st century skills within the context of rigorous academic standards. The concept of 21st century skills does not have a precise definition, but it is intended to convey the idea that changes in technology and culture are leading to changing demands in the workplace, and so the skills that are required in current and future workplace are different from those required in the past [3].

\subsection{Digital Literacy}

In the early 1900s, a person who had acquired simple reading, writing, and calculating skills was considered literate. Today, all students need to learn to read critically, write persuasively, think and reason logically, and solve complex problems in mathematics and science. Digital cameras, graphics packages and streaming video are the means to communicate ideas in a visual and effective way. Students need good visualization skills to be able to decipher, interpret, detect patterns, and communicate using imagery. Digital literacy includes accessing information efficiently and effectively, evaluating information critically and competently, using information accurately and creatively [4].

\subsection{Inventive Thinking}

The interconnectedness of today's world brings with it unprecedented complexity. Interaction in such an environment requires individuals to be able to identify and react to changing conditions independently. Students should become self-directed learners who are able to analyze new conditions as they arise. Professionals should identify new skills that will be required to deal with these conditions and independently chart a course that responds to these changes. They should be able to take into account contingencies, anticipating changes, and understanding interdependencies within systems [4]. 


\subsection{Global Awareness}

Global awareness and international collaboration during schooling period results in more rounded individuals, encouraging students to see things from different perspectives and helping them to make informed decisions, acquiring transferable skills that will be useful to them and will remain with them for life. According to the UKs Association of Graduate Recruiters [5] companies cannot find enough applicants with the requisite skills to operate in an international market place, indicating that greater efforts by schools in fostering global awareness and international collaboration are needed to best prepare students for life and work in the 21st century [6].

\subsection{Creativity and Risk-taking}

Innovation is impossible to achieve without taking a necessary amount of risk. Inevitably, every success sees failures along the way. A teacher should act and teach as an effective innovation leader, encouraging creativity and risk taking, while also practicing a tolerance for failure. Obsolete schooling systems punish failure with low grades. Instead, innovative schooling methods consider the fear of failure as an "innovation killer". Accordingly, failure and risk-talking is being seen and recognized as a learning experience [7]. Creativity and risk-taking leads to a sense of initiative and entrepreneurship. The student acquires the ability to turn ideas into action as well as the ability to plan and manage projects in order to achieve objectives [8].

\subsection{Teamwork}

Information technology plays a key role in the ease with which individuals and groups collaborate. Email, faxes, voice mail, audio and video conferencing, chat rooms, shared documents, and virtual workspaces can provide timely, iterative collaborations. In today's wired, networked society it is imperative that students understand how to communicate using technology. This includes asynchronous and synchronous communication such as person-to-person email interactions, group interactions in virtual learning spaces (such as Learning Management Systems or LMS), chat rooms, interactive videoconferencing, etc. Such interactions require knowledge of etiquette often unique to that particular environment. Other dimensions introduced through global communication include scheduling over time zones, cultural diversity and language issues [4].

\subsection{Learning to Learn}

Learning to learn is the ability to pursue and persist in learning, to organise one's own learning, including through effective management of time and information, both individually and in groups. This competence includes awareness of one's learning process and needs, identifying available opportunities, and the ability to overcome obstacles in order to learn successfully. This competence means gaining, processing 
and assimilating new knowledge and skills as well as seeking and making use of guidance [8].

\section{Preparing the Knowledge Workers of the Knowledge Age}

The adoption of the 21st century skills in schooling will eventually create a new work force known as knowledge workers. Peter Drucker, the management guru, is credited with popularizing the term knowledge worker as long ago as 1968 [9]. Back then he argued, "Today the center is the knowledge worker, the man or woman who applies to productive work ideas, concepts, and information rather than manual skill or brawn... Where the farmer was the backbone of any economy a century or two ago...knowledge is now the main cost, the main investment, and the main product of the advanced economy and the livelihood of the largest group in the population".

The knowledge workers of an organization produce knowledge capital, meaning experience, information, knowledge, learning, and skills. Of all the factors of production, knowledge capital creates the longest lasting competitive advantage of an innovative organization. A knowledge worker, as a producer and bearer of the knowledge capital and also as part of an unseparated whole, becomes the most value asset of his team, his company, his society, his country and therefore of the globalized world. One could argue that a knowledge worker simply signifies a more modern conception of a good job where workers are viewed as more than what they produce, but ultimately it is more than that [10].

Our digital world is currently formed in the Digital Age but moves quickly towards change and gradually is being transformed into the Knowledge Age. Knowledge Age alters the form of entrepreneurship. In Knowledge Age, knowledge and ideas will become the main source of economic growth (more important than land, labor, money, or other tangible resources). As well as this (and this is very important for education), knowledge's meaning is changing. Knowledge is no longer being thought of as 'stuff' that is developed (and stored) in the minds of experts, represented in books, and classified into disciplines. Instead, it is now thought of as being like a form of energy, as a system of networks and flows, something that does things, or makes things happen. In Knowledge Age, knowledge is defined and valued not for what it is, but for what it can do. It is produced, not by individual experts, but by a collective intelligence, meaning groups of people with complementary expertise who collaborate for specific purposes. These changes will eventually alter and define education systems and inexorably will prepare students to become the knowledge workers of tomorrow [11].

\section{Building the future classroom of the Knowledge Age}

Technologically speaking, the school classrooms will become the cradle of the knowledge workers, thus the student and his teachers. From the teachers' point of view it demands understanding and creative use of ICT tools, organizational and administrative competences, use of up-to-date teaching scenarios, intuitive assessment 
methods, project, change and conflict management skills and most of all a "lead and teach by example" attitude. Building the future classroom is all about delivering competent and effective people to the society, people that will be the key stakeholders in a world that seeks innovation and creativity in order to keep going socially, scientifically, economically, etc. From the students' point of view all that is needed is courage, willingness and perseverance. Finally, from the parents' point of view an open-minded and proactive outlook that will permit them to spot and choose the proper schooling environment for their children.

In order to provide to the students significant 21st century skills, a pleiade of ICT tools is needed such as an efficient infrastructure (internet access, multi-touch LCD interactive boards, tablets, email accounts, collaboration and e-learning platforms, video recording and editing equipment, live video-to-video supporting interactive infrastructures like those proposed and implemented by LiveCity EU program, etc.) as well as the proper educational content. The book-based paradigm, which has dominated the organization of schooling for two centuries, can't really become much more efficient [12] and therefore new approaches such as internet research, interactive e-books and teacher-student content co-creation are needed.

\section{Conclusion}

How well we educate our children, whether or not they learn the skills now needed to participate and thrive in global economy, will determine the future health, wealth, and welfare of everyone. This is the good scenario, answering the question \#2 of the introduction: What skills will our child need to be successful in a world twenty years from now? The bad scenario would be to live in conditions of an endless economic depression where unemployment changes from a microeconomic problem into a structural one. In this case the unemployed workers lack the skills needed for the jobs, or they are not living in the part of the country or the world where the jobs are available. This is how our country would simply become in the long run; a no man's / no worker's land. Also, the recent global recession has given us a painful glimpse of what life could be like if we don't succeed in providing our children a 21st century education. Though the causes of the global recession are not directly related to education, the results provide us with an important lesson.

\section{References}

1. Trilling, B. and Fadel, C.: 21st Century Skills: Learning for Life in Our Times, Wiley Desktop Editions, San Francisco (2009)

2. Vretakou, V. and Rousseas, P.: Vocational education in Greece. Cedefop Panorama series 59, p. 13. Office for Official Publications of the European Communities, Luxemburg (2003)

3. Kyllonen, P.C.: Measurement of 21st Century Skills within the Common Core State Standards, In: Invitational Research Symposium on Technology Enhanced Assessments, p. 4. K-12 Center at ETS (2012)

4. The North Central Regional Educational Laboratory, http://enGauge.ncrel.org

5. Association of Graduate Recruiters, http://www.agr.org.uk 
6. Why students need a global awareness and understanding of other cultures. The Guardian Teacher Network, http://www.theguardian.com/teacher-network

7. Innovation is Creativity x Risk Taking, http://www.innovationexcellence.com

8. Key Competences for Lifelong Learning. A European Reference Framework. Official Journal of the European Union, http://ec.europa.eu/dgs/education_culture/publ/eductraining_en.html

9. Drucker, P.F.: The age of discontinuity: Guidelines to our changing society, Transaction Publishers, London (1968)

10.Brinkley, I., Fauth, R., Mahdon, M., Theodoropoulou, S.: Knowledge Workers and Knowledge Work. A Knowledge Economy Programme Report. The Work Foundation, London (2009)

11.The Knowledge Age. New Zealand Council for Educational Research, http://www.shiftingthinking.org/?page_id=58

12.Lloyd, M., Schooling at the Speed of Thought: A blueprint for making schooling more effective, Spiderwize, London (2010) 